\title{
Using Earthworm, Eisenia fetida, to Bio-convert Agro-industrial Wastes for Aquaculture Nutrition
}

\author{
Sonnia N. Musyoka,,${ }^{\mathrm{a}, \mathrm{d} *}$ David M. Liti, ${ }^{\mathrm{b}}$ Eric O. Ogello, ${ }^{\mathrm{c}}$ Paul Meulenbroek, ${ }^{\mathrm{d}}$ and \\ Herwig Waidbacher ${ }^{\mathrm{d}}$
}

\begin{abstract}
Agro-industrial wastes pose great economic and environmental hazards, while the economic success of aquaculture is threatened by the unsustainability of fishmeal use. The aims of the present study were to bio-convert agro-industrial wastes through vermicomposting, and then evaluate the potential of the by-products in promoting aquaculture nutrition. Coffee husks $(\mathrm{CH})$, barley wastes $(\mathrm{BW})$, and kitchen wastes (KW) were pre-composted and inoculated with earthworms, Eisenia fetida, and then vermicomposted for 70 days under a controlled environment. The vermicomposting by-products, i.e., earthworms and vermicast, were amalgamated in the ratio of 1:5 into bedding and then analyzed. There were neither earthworm mortalities nor significant difference $(P>0.05)$ in cocoons produced by $E$. fetida in all treatments. The earthworms grown in KW attained the highest average weight gain of $27.8 \pm 0.7 \mathrm{~g}$, followed by $\mathrm{CH}(24.9 \pm 0.6 \mathrm{~g})$ and $\mathrm{BW}(24.8 \pm 0.7 \mathrm{~g})$. Earthworms grown in $\mathrm{CH}$ and $\mathrm{BW}$ had significantly higher $(\mathrm{P}<0.05)$ nutritional attributes. All experimental wastes produced vermicast with carbon and nitrogen ratios within the preferred agronomic limit of 20 . The nutritional profile of the BW bedding was comparable with that of Caridina nilotica meal and was within the recommended dietary requirements of fish. The wastes can be bio-converted through vermicomposting into various forms appropriate for providing aquaculture nutrition.
\end{abstract}

Keywords: Coffee husks; Barley waste; Kitchen waste; Fish feed; Eisenia fetida; Vermicomposting

Contact information: a: Department of Hydrology and aquatic sciences, South Eastern Kenya University P. O. Box 170 - 90200, Kitui - Kenya; b: Department of Biological Sciences, University of Eldoret, P.O.Box 1125-30100 Eldoret, Kenya; c: Department of Fisheries and Natural Resources, Maseno University, Kenya. P. O. Box private bag, Maseno; d: Department of Water, Atmosphere and Environment, Institute of Hydrobiology and Aquatic Ecosystem Management, University of Natural Resources and Life Sciences, P. O. Box 1180 Vienna, Austria; *Corresponding author: musyokasonia@yahoo.com

\section{INTRODUCTION}

Agro-industrial wastes pose a great economic and environmental hazard, and their safe disposal is major distress to industries. Untreated organic wastes have high chemical and biological oxygen demand, and their uncontrolled disposal causes environmental pollution, landfill, eutrophication, economic losses, health risks, and climate change by producing greenhouse gases (Khuriyati et al. 2015; Degefe et al. 2016). Some of the common agro-industrial wastes include coffee husks, kitchen wastes, and barley wastes. The coffee husks are the discarded outer layer of coffee beans. They constitute up to $25 \%$ of wastes produced during coffee processing (Mbugua et al. 2014). Kitchen waste is the most common form of organic waste in every household. In urban places, every kitchen produces up to $500 \mathrm{~g}$ of wastes, amounts that constitute $70 \%$ of municipal residues (Kale and Sunita 1993; Emperor et al. 2016). On the other hand, the barley wastes consist of bran, stalks, straws, and chaffs collected after sieving the barley grains. The wastes are 
commonly used as animal feeds or in bio-fertilizer and energy production wastes except for coffee husks, which are considered to have low bio-economic value and are thus often land-filled. However, with the heightened environmental concerns and technological advancements, these wastes have attracted research interests on ways to recycle and reuse them as ingredients, supplement feeds, bio-fertilizers, and energy production in fish culture (Ghosh 2004; Prasanthrajan and Kannan 2011; Bakar et al. 2014; Hassan et al. 2016; Jayant et al. 2018). Nonetheless, their use in fish feed production is not highly recommended due to low nutritional value, high fibre contents, presence of endogenous anti-nutritional factors (such as caffeine, alkaloids, and tannins), processing challenges, and bio-safety concerns (Bouafou et al. 2011; Degefe et al. 2016). Nevertheless, the lack of economic success in aquaculture is often caused by either the over-dependence on fishmeal or scarce and expensive commercial fish feeds. These issues have necessitated research on viable biotechnologies such as vermicomposting to bio-convert the organic wastes into forms applicable in fish nutrition.

Vermicomposting is natural and an economical biotechnology of bio-converting agro-industrial residues through the mutual action of earthworms, micro-organisms, and enzymes to stable compounds for safe disposal and bio-fertilizer production (Suthar and Gairola 2014; Bhat et al. 2015; Musyoka et al. 2019). Consequently, vermicomposting biotechnology has been integrated into aquaculture to provide nutrition, directly by supplying earthworm biomass (Zhenjun et al. 2010; Vodounnou et al. 2016) and indirectly by providing vermicast to promote ponds natural productivity (Ghosh 2004). The vermiliquid (liquid phase) provides suitable basal ingredients and source of protein in fish feeds (Zhenjun et al. 2010; Rameshguru and Govindarajan 2011). Additionally, vermicomposting increases palatability, digestibility, and assimilation of the substrates in fish because the fermenting bacterium reduces the anti-nutritional factors such as caffeine and tannins (Hassan et al. 2016; Degefe et al. 2016). Moreover, vermicomposting reduces the bioavailability of heavy metal, suppresses pathogens, and removes toxic acidic compounds, which are associated with the use of agro-industrial wastes in fish feeds (Adhikary 2012). The humic acid produced by earthworms during vermicomposting improves immunity in animals and reduces mycotoxins in feed by inhibiting bacterial and fungal activity (Istiqomah et al. 2009; Adhikary 2012).

The earthworm, Eisenia fetida is credited as a suitable vermicomposting agent vis-à-vis fish feed production. This is because E. fetida has superior nutritional attributes such as amino acid profile comparable to that of fishmeal and relatively high crude protein and lipids contents of up to $76.5 \%$ and $18 \%$ dry matter, respectively (Zakaria et al. 2013; Mohanta et al. 2016; Musyoka et al. 2019). Additionally, it has a relatively high growth rate of $19 \mathrm{mg}$ of worms per day thanks to its voracious nature, whereby it consumes up to half its body weight in a day (Tohidinejad et al. 2011; Vodounnou et al. 2016). Besides, it has the ability to tolerate extreme environmental conditions, for instance, low temperatures and saline environments (Sinha et al. 2009).

Nonetheless, the commercial utilization of the earthworm in aquaculture is limited by processing challenges and the presence of anti-nutritional factors (Tacon et al. 1983; Zhenjun et al. 2010; Kobayashi et al. 2004; Musyoka et al. 2019). The slimy, sticky, and moist nature of the earthworms make handling and harvesting of the worm and cocoons very tedious, labor-intensive, and time-consuming. If poorly handled, E. fetida releases a foul-smelling coelom fluid containing haemolytic factors and lysine, whose presence in earthworm meal causes unpalatability and toxicity to fish, respectively (Tacon et al. 1983; Kobayashi et al. 2004; Vodounnou et al. 2016). Another common challenge of 
using earthworms in fish feed processing is the need to evacuate the gut content of the worm, which lowers the protein content of the earthworm by up to $30 \%$ during analysis (Zhenjun et al. 2010).

The growth performance (weight gain and survival) of earthworms are the parameters used to indicate the success of vermicomposting process (Suthar 2006), while the $\mathrm{C} / \mathrm{N}$ ratio and contents of $\mathrm{P}, \mathrm{K}$, and $\mathrm{Ca}$ in vermicast determine its maturity and applicability in agronomy (Morais and Queda 2003; Adi and Noor 2009; Dabral et al. 2013; Suthar and Gairola 2014; Degefe et al. 2016). The nutritional compositions (principally protein and amino acid profile) are the key attributes considered when selecting a potential fish diet or fishmeal replacer. There are various studies on vermicomposting agro-industrial wastes then using the by-products (earthworms, vermicast, and vermiliquid) separately in aquaculture nutrition. However, there is limited scientific data indicating amalgamating the vermicomposting by-products into earthworm bedding (i.e., a mixture of earthworms, vermicast, and vermiliquid) for fish feed production. Therefore, the aim of the present study was to evaluate the potential of coffee husks $(\mathrm{CH})$, barley waste $(\mathrm{BW})$, and kitchen waste $(\mathrm{KW})$ as substrates for culturing earthworms as well as a source of nutrition for aquaculture in form of vermicast (for fertilizing semi-intensive ponds), earthworm biomass (as fish feed protein source), and bedding meal (as an ingredient or whole diet for aquatic organisms). The simple biotechnology would provide scientific information on how to overcome some of the challenges associated with commercial utilization of earthworms and agro-industrial wastes in fish feed production. This biotechnology has the potential to be scaled to commercial levels to promote sustainable fish yields and optimize resource utilization, thus improving food security and environmental integrity.

\section{EXPERIMENTAL}

\section{Selection of Agro-industrial Wastes and Earthworms}

The BW and freshwater shrimp (Caridina nilotica) meal were procured from Gikomba open market in Nairobi, Kenya. The $\mathrm{CH}$ was obtained from coffee factories within Kiambu and Machakos Counties, Kenya. The KW was used as a control experiment because they are rich in organic matter, contains high nitrogen content, faster in decomposition rate and has been proven to promote growth in earthworms and fish (Ada and Noor 2009; Mo et al. 2014; Vodounnou et al. 2016). Non-acidic and less greasy organic KW (mainly fruit peelings, vegetable remains, and eggshells) and urine-free cattle manure were collected from nearby households. The E. fetida was procured from the Kamuthanga farm, in Machakos, Kenya and acclimatized for two weeks by feeding them with a mixture of the three pre-composted test culture substrates, i.e., $\mathrm{CH}, \mathrm{BW}$, and KW in the ratio of $1: 1: 1$.

\section{Pre-composting of Substrates}

Before the utilization of the substrates in earthworm culture, each substrate was mixed with $10 \%$ urine free cattle manure. The inclusion of manure during precomposting provides nitrogen, stimulates biodegradation and increases the $\mathrm{pH}$ of culture substrates (Loh et al. 2005; Adi and Noor 2009; Bhat et al. 2015). The substrates were then pre-composted for two weeks by adding water and turning it every 48 hours. This increased the substrate acceptability because earthworms do not survive on fresh 
livestock and vegetable wastes (Gunadi and Edwards 2003). Pre-composting reduces anaerobic conditions in manure, which normally causes worm mortality during the second week of vermicomposting (Gunadi and Edwards 2003; Adi and Noor 2009).

\section{Infrastructure}

Each treatment was replicated six times; therefore, there were a total of 18 culture units. The culture units were plastic cylindrical buckets with a capacity to hold 80 litres. Each bucket was served with $2500 \mathrm{~g}$ of the respective pre-composted substrate then inoculated with 60 preclitellate earthworms with initial weight and length of $0.25 \pm 0.05 \mathrm{~g}$ and $3.61 \pm 0.39 \mathrm{~cm}$, respectively.

The experiment was conducted for 70 days (10 weeks) because this is the time $E$. fetida is expected to reach its full sexual maturity, which under favorable conditions happens between the $3^{\text {rd }}$ and $10^{\text {th }}$ week (Tripathi and Bhardwaj 2004). The culture buckets were placed in a dark, well-ventilated room. The substrates were regularly sprinkled with cold lime water to regulate moisture, $\mathrm{pH}$, and temperature to optimum levels of between $80 \%$ to $90 \%, 5$ to 9 , and $20{ }^{\circ} \mathrm{C}$ to $30{ }^{\circ} \mathrm{C}$, respectively (Gunadi and Edwards 2003). The worms were monitored regularly for mortalities, color change, escapes, maggot/flies, foul smell, and presence of cocoons. During the weekly sampling of weight, all new cocoons were counted and discarded. This was to ensure only the original earthworms were returned into their respective culture buckets and no increment in worm numbers.

At the end of the experiment, E. fetida from each test substrate were pooled and analyzed for moisture, protein, crude fibre, ash, and crude lipids. The vermicast from each culture bin was collected, dried, and tested for C, N, P, K, Ca, and crude lipid. Each treatment had their E. fetida and vermicast mixed in the ratio of 1:5, poured into a metallic foil paper, frozen immediately to kill the worms, and then crushed to form earthworm beddings. The earthworm beddings were sundried, ground, sieved, and analyzed for nutritional profile (moisture, protein, fibre, ash, lipids, amino acids), then compared to that of $C$. nilotica meal, Nile tilapia (Oreochromis niloticus), and shrimp (Penaeus monodon).

\section{Biochemical Analysis}

The proximate biochemical analysis of the test samples was done in triplicates according to the AOAC (1995) standards. The moisture content was determined by oven drying the samples at $70^{\circ} \mathrm{Cuntil}$ a constant weight was attained. The vermicasts were analyzed for $\mathrm{C}$ using the partial oxidation method as demonstrated by Dynoodt and Sharifudin (1981), while N was estimated using Kjeldahl process of digesting, distilling and titrating the samples using sulphuric acid, sodium hydroxide, and boric acid, respectively. Phosphorus was determined using a calorimetric method with sulphuric acid and molybdenum, as described by Tandon (1993), whereas the atomic absorption method of ignition was used to measure the $\mathrm{K}$ and Ca contents (Loh et al. 2005). The earthworm and bedding samples had their protein analysis done using the Lowry (Folin) method described by Lowry et al. (1951). The Lowry (Folin) method was preferred over the Kjeldahl digestion to exclude the ammonia and any other nitrogenous compounds produced during vermicomposting (Gunadi and Edwards 2003; Degefe et al. 2016; Musyoka et al. 2019). Consequently, true protein from the earthworms and beddings was estimated by creating a calibration graph after reducing Folin-Ciocalteu reagent by tyrosine through reacting peptide bonds together with copper ions. The crude fibre was 
determined by the acid-base hydrolysis method of using sulphuric acid and sodium hydroxide to degrade cellulose and lignin. Low-boiling point petroleum ether (40 to 60 ${ }^{\circ} \mathrm{C}$ ) was used to extract solvents from the samples to determine the crude lipid. The essential amino acid profile of the beddings was profiled using the procedure described by Prisecaru and Baianu (2011). The samples were measured using an integrating sphere in MPA FT-NIR spectroscopy and calibrated using calibration packages obtained from INGOT® and Bruker, Germany.

\section{Growth Parameters and Survival (\%)}

The suitability for each substrate to culture worms was determined by calculating the growth rate and the specific growth rate (SGR).

$$
\begin{aligned}
& \text { Weight gain }(\mathrm{g})=\text { final weight }(\mathrm{g})-\text { initial weight }(\mathrm{g}) \\
& \text { Survival }(\%)=(\text { initial number/final number }) \times 100 \\
& \text { SGR }=100 \times[\operatorname{Ln}(\text { Final weight }(\mathrm{g}))-\text { Ln }(\text { Initial weight }(\mathrm{g}))] / \text { time }
\end{aligned}
$$

\section{Data Analysis}

The data were expressed as mean \pm standard deviation (SD), and the analysis was performed using SPSS (Statistical software package) version 17.0. Univariate analysis was used to determine statistical differences between means. If significant differences $(p<0.05)$ were observed, the differences among the means were compared using Tukey's post hoc test at $5 \%$ probability level.

\section{RESULTS AND DISCUSSION}

\section{Growth Performance of Earthworms}

The weight gain was significantly different $(\mathrm{P}<0.05)$ in all treatments. The $E$. fetida grown in KW (control) substrate had significantly high $(\mathrm{P}<0.05)$ average weight gain of $27.8 \pm 0.6 \mathrm{~g}$ followed by $24.9 \pm 0.7 \mathrm{~g}$ and $24.8 \pm 0.7 \mathrm{~g}$ in $\mathrm{CH}$ and $\mathrm{BW}$, respectively, as shown in Table 1 . The average SGR was significantly high in E. fetida grown in $\mathrm{KW}$ $(0.9 \pm 0.0)$, followed by earthworms grown in $\mathrm{BW}(0.8 \pm 0.0)$, then least in $\mathrm{CH}(0.7 \pm$ $0.1)$. There were no earthworm mortalities recorded during the entire culture period. Similarly, there was no variation in the number of cocoons produced by all earthworms.

Earthworm survival, growth, maturation, and reproduction depend on the quantity and biochemical quality of culture substrate, food particle size, stocking density, and environment (Tacon et al. 1983; Tripathi and Bhardwaj 2004; Prasanthrajan and Kannan 2011; Dabral et al. 2013; Vodounnou et al. 2016). An appropriate vermicomposting material should promote earthworm growth and reproduction within the stipulated time. The lack of mortalities and cocoon production in the current study were indications that the environment provided was conducive and the substrate provided quality and quantity food to the earthworms, whose availability has a positive correlation with E. fetida growth and reproduction (Prasanthrajan and Kannan 2011; Dabral et al. 2013). Additionally, the close-range biomass gain in all treatments is an indication that the substrates had metabolizable organic matter content, optimized growth of microbes, less growth retarding chemicals, were palatable, and contained non-assimilated carbohydrates (Prasanthrajan and Kannan 2011; Bakar et al. 2014; Degefe et al. 2016). It is important to note that the earthworm biomass produced in the present study can be up-scaled to supply 
fish nutrition commercially in various intensities of fish farming because the quantity of a diet is the second aspect after nutrition considered when selecting sustainable fish feeds.

Table 1. Weight (G) and Cocoon Performance (Mean \pm SD) of Eisenia fetida and Vermicompost (Cast) Analysis (\% Dry Matter) in Different Substrates

\begin{tabular}{|c|c|c|c|c|}
\hline Variables & Weight Gain & SGR & Cocoons & Survival \\
\hline $\mathrm{CH}$ & $24.85 \pm 0.6^{a}(.9)$ & $0.67 \pm 0.08^{a}(.0)$ & $9.17 \pm 1.83^{\mathrm{a}}(.9)$ & $100 \pm 0^{\mathrm{a}}(1)$ \\
\hline BW & $24.8 \pm 0.74^{\mathrm{a}}(.9)$ & $0.76 \pm 0.04^{\mathrm{b}}(.0)$ & $9.33 \pm 1.63^{a}(.9)$ & $100 \pm 0^{a}(1)$ \\
\hline KW & $27.82 \pm 0.74^{\mathrm{b}}(.0)$ & $0.89 \pm 0.04^{\mathrm{c}}(.0)$ & $9 \pm 2.1 \mathrm{a}(.9)$ & $100 \pm 0^{\mathrm{a}}(1)$ \\
\hline Variables & Cast $P$ & Cast K & Cast $\mathrm{Ca}$ & Cast C \\
\hline $\mathrm{CH}$ & $0.28 \pm 0.0^{\mathrm{b}}(.0)$ & $0.36 \pm 0.05^{\mathrm{a}}(.0)$ & $3.46 \pm 0.34^{b}(.0)$ & $15.97 \pm 0.69^{c}(.0)$ \\
\hline BW & $0.2 \pm 0.02^{a}(.0)$ & $0.56 \pm 0.04^{b}(.0)$ & $2.8 \pm 0.06^{\mathrm{a}}(.0)$ & $11.62 \pm 0.28^{\mathrm{a}}(.0)$ \\
\hline KW & $0.35 \pm 0.1^{b}(.0)$ & $0.66 \pm 0.03^{c}(.0)$ & $4.13 \pm 0.42^{\mathrm{c}}(.0)$ & $12.87 \pm 1.01^{\mathrm{b}}(.0)$ \\
\hline Variables & Cast N & Cast $\mathrm{C} / \mathrm{N}$ & Cast Crude lipids & \\
\hline $\mathrm{CH}$ & $1.02 \pm 0.07^{a}(.0)$ & $15.68 \pm 0.95^{b}(.0)$ & $6.52 \pm 0.19^{a}(.0)$ & \\
\hline BW & $3.15 \pm 0.5^{b}(.0)$ & $3.75 \pm 0.54^{\mathrm{a}}(.0)$ & $8.45 \pm 0.15^{b}(.0)$ & \\
\hline KW & $1.04 \pm 0.44^{\mathrm{a}}(.0)$ & $13.57 \pm 3.79^{\mathrm{b}}(.0)$ & $9.47 \pm 0.38^{c}(.0)$ & \\
\hline \multicolumn{5}{|c|}{$\begin{array}{l}\text { Means with different superscript letters }(a<b<c) \text { in the same column are significantly } \\
\text { different } P<0.05\end{array}$} \\
\hline
\end{tabular}

\section{Maturity of the Vermicast}

There was a significant difference $(\mathrm{P}<0.05)$ in all of the nutritional parameters tested. The highest contents of $\mathrm{P}, \mathrm{K}$, and $\mathrm{Ca}$ were observed in the vermicasts from $\mathrm{KW}$, followed by $\mathrm{CH}$ then $\mathrm{BW}$. The $\mathrm{C}$ and $\mathrm{N}$ contents were inversely proportional, with the highest contents being observed in $\mathrm{CH}$ and $\mathrm{BW}$, respectively. Consequently, the $\mathrm{C} / \mathrm{N}$ ratio was significantly higher $(\mathrm{P}<0.05)$ in $\mathrm{CH}$ and lower in $\mathrm{BW}$. The crude lipid content in the vermicast was in the order of $\mathrm{KW}>\mathrm{BW}>\mathrm{CH}$.

Apart from earthworm growth performance, the nutritional constituent of vermicast can establish the suitability of organic material for vermicomposting vis-à-vis organic fertilizer production. The $\mathrm{P}, \mathrm{K}$, and $\mathrm{Ca}$ contents are key components in organic fertilizer production. The $\mathrm{P}$ and $\mathrm{Ca}$ contents observed in all treatments in the current study were relatively higher than those recorded by Ada and Noor (2009) on vermicasts of coffee grounds and kitchen wastes spiked with cow dung. This shows the $\mathrm{CH}$ and BW promoted growth of earthworm gut micro-organisms, which are responsible for the mineralization, mobilization, solubilization, and stabilization of micronutrients during vermicomposting (Aira et al. 2006; Suthar and Gairola 2014).

A suitable vermicast should have a $\mathrm{C} / \mathrm{N}$ ratio below 15 ; however, any amount not above 20 is still acceptable for agronomic purposes (Morais and Queda 2003). Therefore, all the experimental wastes in the present study produced mature vermicast. The relatively low organic $\mathrm{C}$ and high $\mathrm{N}$ in $\mathrm{BW}$ casts show this waste was of good quality, hence easily metabolized and mineralized by earthworms and microbes, respectively (Suthar 2006; Suthar and Gairola 2014). The enrichment of $\mathrm{N}$ contents during vermicomposting is also enhanced by the nitrogen-fixing bacteria, earthworm secretions, and microbial mineralization of non-nitrogenous matter (Suthar 2006; Suthar and Gairola 2014). The significantly high $(\mathrm{P}<0.05)$ organic $\mathrm{C}$ in $\mathrm{CH}$ (despite the uptake by 
earthworms) could be due to the presence of fungal and microbial biomass, whose presence and richness is an indicator of quality and mature vermicast (Aira et al. 2006). The crude lipid content is another essential indicator of a suitable vermicomposting substrate. The relatively high crude lipid observed in $\mathrm{KW}$ casts is believed to be due to the presence of some animal-based remains (Adi and Noor 2009). The superior nutritional composition of the vermicast from the present study shows the vermicomposting by-product can be applied in semi-intensive ponds to improve fish yield by promoting pond primary production, enhancing water retention and stabilizing the bottom sediment (Ghosh 2004).

\section{Biochemical Analysis of Eisenia fetida}

There was a significant difference $(\mathrm{P}<0.05)$ in the proximate composition of $E$. fetida grown in all substrates. The moisture content was in the order of $\mathrm{CH}>\mathrm{BW}>\mathrm{KW}$, while both the ash and crude lipid contents were significantly high $(\mathrm{P}<0.05)$ in E. fetida grown in $\mathrm{CH}$, as shown in Table 2. The crude fibre and protein were in the order of $\mathrm{CH}>\mathrm{BW}>\mathrm{KW}$ and $\mathrm{BW}>\mathrm{CB}>\mathrm{KW}$, respectively.

The unsustainable fish feed industry has created opportunities to investigate nonconventional protein sources for fish feed production. Aquaculture nutrient requirements depend on fish size, age, dietary protein source, energy content, culture conditions, and water quality. Depending on fish culture systems, the diet nutrition component constitutes an estimated $50 \%$ of operating costs, with the protein itself representing up to $50 \%$ of the feed cost. To realize financial success, every fish farmer should obtain sustainable (quality and quantity) feed at the least cost possible. The protein, ash, fibre, and lipids are the basic nutritional components considered when selecting fish feed.

Table 2. Proximate Composition (Mean $\pm S D$ ) of Eisenia fetida on \% Dry Matter

\begin{tabular}{|l|l|l|l|l|l|}
\hline Variables & Moisture & Ash & Crude protein & Crude fibre & Crude lipids \\
\hline E. fetida grown in CH & $78.4 \pm 0.5^{\mathrm{a}}(.0)$ & $9.73 \pm 1.76^{\mathrm{b}}(.0)$ & $51.03 \pm 2.05^{\mathrm{a}}(.0)$ & $14.77 \pm 1.91^{\mathrm{b}}(.0)$ & $5.57 \pm 0.95^{\mathrm{b}}(.0)$ \\
\hline $\begin{array}{l}\text { E. fetida grown in } \\
\text { BW }\end{array}$ & $79.5 \pm 0.6^{\mathrm{b}}(.0)$ & $6.77 \pm 1.08^{\mathrm{ab}}(.0)$ & $57.53 \pm 1.34^{\mathrm{b}}(.0)$ & $13.33^{\prime} \pm 0.58^{\mathrm{ab}}(.0)$ & $3.8 \pm 0.0^{\mathrm{a}}(.0)$ \\
\hline $\begin{array}{l}\text { E. fetida grown in } \\
\text { KW }\end{array}$ & $81.8 \pm 0.2^{\mathrm{c}}(.0)$ & $4.17 \pm 1.04^{\mathrm{a}}(.0)$ & $50.5 \pm 3.17^{\mathrm{a}}(.0)$ & $10.4 \pm 1.05^{\mathrm{a}}(.0)$ & $3.37 \pm 0.21^{\mathrm{a}}(.0)$ \\
\hline
\end{tabular}

Eisenia fetida contains nutritional attributes (protein and amino acids) comparable to fishmeal (Tacon et al. 1983; Dedeke et al. 2010; Zakaria et al. 2013; Vodounnou et al. 2016; Mohanta et al. 2016; Musyoka et al. 2019). The nutritional profile of the earthworm is determined by the dietary content of the substrate and processing (handling, harvesting, killing, drying, gut evacuation, and testing procedures) techniques (Musyoka et al. 2019). The result obtained in the current study shows that BW has relatively high nutritional qualities compared with the other substrates. The crude protein of $E$. fetida grown in BW was higher than the $54.6 \%$ and $52 \%$ dry matter obtained by Zhenjun et al. (2010) and Mohanta et al. (2016), respectively. However, all the crude protein contents of E. fetida in the current study were lower than the $76.5 \%$ and $71 \%$ dry matter documented by Zakaria et al. (2013) and Zhenjun et al. (2010), respectively. Unlike these studies, the current study did not evacuate the gut content of the worms before analysis. The presence of the gut contents during analysis possibly lowered the crude protein 
content and probably increased the fibre and ash contents (Zhenjun et al. 2010). Conversely, the current study opted to include the gut contents in the tests for the simple fact of the applicability of the utilization of the earthworm by fish farmers, who might not have the technologies of harvesting and removing the gut contents. The relatively high crude protein in $E$. fetida grown in $\mathrm{BW}$ shows that the presence of a quality substrate in the earthworm gut does not significantly affect the protein content of the worms and its consequent probable inclusion content in fish feed formulation.

\section{Biochemical Analysis of Beddings}

There was a significant difference $(\mathrm{P}<0.05)$ between the nutritional components of the beddings and the freshwater shrimp meal, as shown in Table 3. The moisture contents were significantly $(\mathrm{P}<0.05)$ higher in the beddings than in $C$. nilotica, while the ash content and crude fibre were in the order of $\mathrm{CH}>\mathrm{KW}>\mathrm{BW}>C$. nilotica and $\mathrm{KW}>\mathrm{CH}>\mathrm{BW}>C$. nilotica, respectively. The protein content in $C$. nilotica was significantly higher $(\mathrm{P}<0.05)$ than the level obtained in all the beddings. However, all beddings had higher crude lipids than the $C$. nilotica and those required by $O$. niloticus and $P$. monodon. The protein content of $\mathrm{BW}$ was within the optimal recommended requirements of tilapia and shrimps by FAO (2019) and Boonyaratpalin (1996). Nonetheless, the protein contents in all beddings were appropriate for a semi-intensive farming system, whereby fish do not require diets with optimal nutrition due to the presence of natural feed sources (Mjoun et al. 2010). The recommendable protein contents in all beddings were enhanced by earthworm biomass and fungi community accrual, which improve protein yields during vermicomposting (Dedeke et al. 2010; Pramanik and Chung 2011). The elevated crude lipid contents in a feed is an attribute important in semi-intensive farming, whereby fish utilize phospholipids from supplementary diet to supply energy, thus reserving proteins from natural sources for tissue growth (Liti et al. 2005). On the contrary, the high fibre content in a diet reduces the bio-availability of nutrients, thus suppressing fish growth. Notably, the beddings did not have as much ash content as is normally found in plant materials due to the presence of earthworm biomass, which is known to have low fibre contents (Tacon et al. 1983; Istiqomah et al. 2009).

Table 3. Comparison of Biochemical Characteristics (Mean $\pm S D$ ) of Beddings (\% Dry Matter), Fishmeal (Caridina nilotica), and the Nutritional Requirement of Oreochromis niloticus and Penaeus monodon on Dry Matter

\begin{tabular}{|c|c|c|c|c|c|}
\hline Variables & Moisture & Ash & Protein & Crude Fibre & Crude Lipids \\
\hline $\begin{array}{l}\mathrm{CH} \\
\text { bedding }\end{array}$ & $79.77 \pm 1.08^{\mathrm{b}}(.0)$ & $11.53 \pm 0.21^{\mathrm{c}}(.0)$ & $25.17 \pm 1.46^{\mathrm{a}}(.0)$ & $18.93 \pm 0.7^{\mathrm{c}}(.0)$ & $6.5 \pm 0.56^{a}(.0)$ \\
\hline $\begin{array}{l}\text { BW } \\
\text { bedding }\end{array}$ & $79.6 \pm 0.96^{b}(.0)$ & $10 \pm 0.5^{b}(.0)$ & $39.17 \pm 1.11^{b}(.0)$ & $12.07 \pm 0.12^{\mathrm{b}}(.0)$ & $8.63 \pm 0.47^{b}(.0)$ \\
\hline $\begin{array}{l}\text { KW } \\
\text { bedding }\end{array}$ & $80.53 \pm 0.64^{b}(.0)$ & $10.5 \pm 0.92^{b}(.0)$ & $23.57 \pm 0.67^{a}(.0)$ & $19.87 \pm 0.23^{d}(.0)$ & $8.6 \pm 0.87^{b}(.0)$ \\
\hline C. nilotica & $20.2 \pm 0.79^{\mathrm{a}}(.0)$ & $6.23 \pm 0.06^{a}(.0)$ & $59.63 \pm 0.67^{c}(.0)$ & $9.43 \pm 0.15^{\mathrm{a}}(.0)$ & $6.03 \pm 0.25^{\mathrm{a}}(.0)$ \\
\hline Tilapia $^{1}$ & - & - & $30-35$ & $8-10$ & $10-15$ \\
\hline Shrimp ${ }^{2}$ & - & - & $28-30$ & - & $3-7$ \\
\hline \multicolumn{6}{|c|}{1 - Dietary requirement for O. niloticus (FAO 2019) } \\
\hline \multicolumn{6}{|c|}{2 - Dietary requirement for Penaeus monodon (Boonyaratpalin 1996) } \\
\hline \multicolumn{6}{|c|}{ Means with different superscript letters $(\mathrm{a}<\mathrm{b}<\mathrm{c}<\mathrm{d})$ in the same column are significantly different at $P<0.05$} \\
\hline
\end{tabular}




\section{Comparison of Amino Acid Contents of the Beddings}

There was no significant difference $(\mathrm{P}>0.05)$ between essential amino acids of all beddings and $C$. niloticus except for isoleucine, as shown in Table 4 . The amino acids isoleucine, leucine, arginine, valine, phenylalanine, histidine, and threonine (of BW) in the earthworm beddings were comparable to that found in $C$. nilotica and were within the requirements of $O$. niloticus as recommended by Santiago and Lovell (1988). It was only the isoleucine and histidine contents of all the beddings that were within the dietary requirements of $P$. monodon. Only methionine, lysine, and tryptophan contents were considerably lower in all beddings than those of $C$. nilotica and recommended requirements of $O$. niloticus and $P$. monodon thanks to the presence of plant-based proteins from the agro-industrial wastes.

The close-range relationship between amino acid levels in all beddings and that of C. nilotica could be attributed to the presence of E. fetida, which is known to have comparable nutritional attributes with fishmeal (Dedeke et al. 2010; Vodounnou et al. 2016; Musyoka et al. 2019). Methionine and lysine are the primary limiting amino acids when fishmeal is reduced, or feed is obtained from plant-based sources (Djissou et al. 2016). The close to optimal nutritional composition observed in all earthworm beddings shows they have the potential of either being an ingredient in fish feeds or a whole diet for aquatic organisms. However, there is a need to supplement earthworm bedding meals with the deficient amino acids to fulfill the dietary requirements of the cultured species, particularly the shrimps. This is because the amino acid profile and digestibility determine the value of proteins in any diet. Subsequently, its composition determines the feed intake, absorption, assimilation, and eventual growth as well as reproduction and immunity in fish. The amalgamation of the vermicomposting by-products to bedding avoided the need to harvest and evacuate the gut content of E. fetida, thus simplifying the earthworm processing. It further reduced the stress-related complications associated with conventional earthworm handling and harvesting, which prompts E. fetida to release the foul-smelling and toxic coelom fluid in defense. 


\section{Conflict of Interest Statement}

There is no conflict of interests among the five authors whose names are listed in the Manuscript. The authors have no financial or non-financial interests in the topic review of the manuscript.

\section{Ethical Statement}

This is an original work and it has been neither submitted nor published elsewhere as a whole in part. The authors are responsible for all the content in the Manuscript.

\section{Data Availability Statement}

The datasets related to this article are available at Mendeley datasets on the following link (https://data.mendeley.com/datasets/ny59dz4r3t/draft?a=3ec57d0b-55fa4cba-b75f-e3dff86aba2d).

\section{Data Citation Statement}

All data used in this article was cited and referenced accordingly and can only be availed through the request and permission of the third-party authors.

\section{Animal Ethical Statement}

The authors certify that the current study followed all the applicable guidelines for the care and use of animals.

\section{REFERENCES CITED}

Adi, A. J., and Noor, Z. M. (2009). "Waste recycling: Utilization of coffee grounds and kitchen waste in vermicomposting," Bio. Tec. 100(2), 1027-1030. DOI: 10.1016/j.biortech.2008.07.024

Adhikary, S. (2012). "Vermicompost, the story of organic gold: A review," Agric. Scien. 3(7), 905-917. DOI: 10.4236/as.2012.37110

Aira, M., Monroy, F., and Dominguez, J. (2006). "Eisenia fetida (Oligochaeta, Lumbricidae) activates fungal growth, triggering cellulose decomposition during vermicomposting," Microb. Ecol. 52, 738-746.DOI: 10.1007/s00248-006-9109-x

Association of Official Analytical Chemists (AOAC) (1995). Official Methods of Analysis (16 ${ }^{\text {th }}$ Ed.), Arlington, VA, USA.

Bakar, A. B, Afzan, S. N, Gawi, S. M., Mahmood, N. Z., and Abdullah, N. (2014). "Vermicomposting of vegetable waste amended with different sources of agroindustrial by-product using Lumbricus rubellus," Pol. J. Environ. Stud. 23(5), 14911498.

Bhat, S. A., Singh, J., and Vig, A. P. (2015). "Potential utilization of bagasse as feed material for earthworm Eisenia fetida and production of vermicompost," Int. J. Recycl. Org. Waste. Agric. 4, 11.DOI: 10.1186/s40064-014-0780-y

Boonyaratpalin, M. (1996). "Nutritional requirements of commercially important shrimps in the tropics," 10-28, in: C. B. Santiago, R. M. Coloso, O. M. Millamena, and I. G. Borlongan (eds.), Feeds for Small-Scale Aquaculture, Proceedings of the National Seminar-Workshop on Fish Nutrition and Feeds, Philippines.

Bouafou, M., Kouamé, G., Konan, B. A., Zannou-Tchoko, V., and Kati-Coulibally S. (2011). "Potential food waste and by-products of coffee in animal feed," Electr. J. 
Biol 7(4), 74-80.

Dabral, M., Joshi, N., Maikhuri, R. K., Joshi, A., and Dabral, S. P. (2013). "Effect of diet on feeding and casting activities of earthworms (Drawida nepalensis) and response of crop growth," Trop. Ecol. 54(3), 375-381.

Dedeke, G. A., Stephen, O. O., and Kayode, B. O. (2010). "Amino acid profile of four earthworms species from Nigeria," Agric. Biol. J. of Nor. Ame. 1, 97-102.

Degefe, G., Mengistou, S., and Mohammed, S. (2016). "Physico chemical evaluation of coffee husk, wastes of enset (Enset ventricosum), vegetable and khat (Catha edulis) through vermicomposting employing an epigeic earthworm Dendrobaena veneta (Rosa, 1886)," Afr. J. of Biot. 1520, 884-890.

Djissou, S., Adjahouinou, D. C., Koshio, S., and Fiogbe, E. D. (2016). “Complete replacement of fishmeal by other animal protein sources on growth performance of Clarias gariepinus fingerlings," Intern. Aquac. Res. 8(4), 333-341. DOI:

10.1007/s40071-016-0146-X

Dynoodt, P., and Sharifudin, A. (1981). "Basic guide to soil and plant analyses," Tech. B. Fac. of Agri., pp. 55.

Emperor, G.N., Kumar, K., and Ravikumar, G. (2016). "Growth performance and hatchling rate of Eudrilus eugeniae and Eisenia fetida in different concentrations of tea waste, cow dung and kitchen waste mixture," As. J. of Inn. Res. 1(1), 46-52.

FAO (2019). "Nile tilapia - Nutritional requirements. Aquaculture Feed and Fertilizer Resources Information System," (http://www.fao.org/fishery/affris/speciesprofiles/nile-tilapia/nile-tilapia-home/en/), Accessed on date $15^{\text {th }}$ April 2019.

Ghosh, C. (2004). "Integrated vermi-pisciculture-An alternative option for recycling of solid municipal waste in rural India," Bio. Tec. 93(1), 71-75. DOI:

10.1016/j.biortech.2003.09.014

Gunadi, B., and Edwards, C. A. (2003). "The effect of multiple applications of different organic wastes on the growth, fecundity and survival of Eisenia fetida (Savigny) (Lumbricidae)," Pedo. 47(4), 321-330. DOI: 10.1078/0031-4056-00196

Hassan, M. A., Aftabuddin, M., Meena, D. K., Mishal, P., and Das Gupta, S. (2016). "Effective utilization of distiller's grain soluble-Anagro-industrial waste in the feed of cage-reared minor carp Labeobata in a tropical reservoir, India," En. Sci. Pol. Res. Inte. 23(16), 16090-16095. DOI: 10.1007/s11356-016-6732-z

Istiqomah, L., Sofyan, A., Damayanti, E., and Julendra, H. (2009). "Amino acid profile of earthworm and earthworm meal (Lumbricus rubellus) for animal feedstuff," $J$. of Indon. Trop. Ani. Agric.34(4), 253-257.DOI: 10.14710/jitaa.34.4.253-257.

Jayant, M., Hassan, M., Srivastava, P., Meena, D., Kumar, P., Kumar, A., and Wagde, M. (2018). 'Brewer's spent grains (BSGs) as feedstuff for striped catfish, Pangasianodon hypophthalmus fingerlings: An approach to transform waste into wealth," J. of Cle. Prod.199, 716-722.

Kale, R. D., and Sunita, N. S., (1993). "Utilization of earthworms in recycling of household refuse a case study in Biogas slurry utilization, New Delhi," Cos. on Ru. Tech, pp.75-79.

Kobayashi, H., Ohta, N., and Umeda, M. (2004). "Biology of lysenin, a protein in the coelomic fluid of the earthworm Eisenia fetida," Intern. Rev. of Cytol.236, 45-99. DOI: 10.1016/S0074-7696(04)36002-X

Khuriyati, N., Wagiman, K., and Kumalasari, D. (2015). "Cleaner production strategy for improving environmental performance of small scale cracker industry," Agri. and Agri. Sci. Proc. 3, 102-107. DOI: 10.1016/j.aaspro.2015.01.021. 
Liti, D., Kerogo, L., Munguti, J. M., and Chorn, L. (2005). "Growth and economic performance of Nile tilapia (Oreochromis niloticus) fed on two formulated diets and two locally available feeds in fertilized ponds," Aquac. Res. 36(8), 746-752. DOI: 10.1111/j.1365-2109.2005.01265.x

Loh, T. C., Lee, Y. C., Liang, J. B., Tan, D. (2005). "Vermicomposting of cattle and goats manures by Eisenia foetida and their growth and reproduction performance," Bio. Tec. 96(1), 111-114. DOI: 10.1016/j.biortech.2003.03.001

Lowry, O., Nira, J., Rosebrough, A., Farr, L., and Randall, J. (1951). "Reagent protein measurement with the Folin phenol," J. Biol. Chem.193, 265-275.

Mbugua, M. W., Kimani M. W., Njoroge B. N. K., Gitau A. N., Mutua J. M., and Luvai A. K. (2014). "Characterization of the physical parameters of coffee husks towards energy production," Int. J. of Em. Tech. and Adv. Eng. 4(9), 715-720.

Mjoun, K., Rosentrater, K. and Brown, L. (2010). Tilapia: Environmental Biology and Nutritional Requirements (SDSU Extension Fact Sheet 164), (http://openprairie.sdstate.edu/extension_fact/164).

Mo, W.vY., Cheng, Z., Choi, W. M., Man, Y. B., Liu, Y., and Wong M. H. (2014). "Application of food waste based diets in polyculture of low trophic level fish: effects on fish growth, water quality and plankton density," Mar. Poll. Bull. 85, 803-809. DOI: 10.1016/j.marpolbul.2014.01.020

Mohanta, K. N., Sankaran, S., and Veeratayya, S. (2016). "Potential of earthworm Eisenia fetida as dietary protein source for rohu (Labeo rohita) advanced fry," Cog. Fo. and Agric. 2, 1. DOI: 10.1080/23311932.2016.1138594

Morais, F. M., and Queda, C. A. (2003). "Study of storage influence on evolution of stability and maturity properties of MSW composts," in: Proceeding of the Fourth International Conference of ORBIT Association on Biological Processing of Organics, Advances for a Sustainable Society Part II, Perth, Australia.

Musyoka, S. N., Liti, D. M., Ogello, E., Waidbacher, H. (2019). "Utilization of the earthworm, Eisenia fetida (Savigny, 1826) as an alternative protein source in fish feeds processing: A review," Aquac. Res. 50(9), 2301-2315.

Pramanik, P., and Chung, Y. R. (2011). "Changes in fungal population of fly ash and vinasse mixture during vermicomposting by Eudriluse ugeniae and Eisenia fetida, documentation of cellulose isozymes in vermicompost," Was. Man. 31, 11691175.DOI: 10.1016/j.wasman.2010.12.017

Prasanthrajan, J., and Kannan, J. (2011). "Assessing the growth of earthworms with respect to environmental factor and feeding materials," Cro. Res. 41, 253-254.

Prisecaru, V., and Baianu, C. (2011). "A novel NIR spectroscopy correlation approach to amino acid analysis of soybean proteins for composition improvements," Nature Proceedings. DOI: 10.1038/npre.2011.6231.4

Rameshguru, G., and Govindarajan, B. (2011). "Study on growth of Oreochromis mossambicus fed with Vermiwash (earthworm coelomic fluid) diet," J. of Bios. Reso. 2(4), 232-238.

Santiago, C., and Lovell, R. (1988). "Amino acid requirements for growth of Nile tilapia," J. Nutr. 118(12), 1540-1546. DOI: 10.1093/jn/118.12.1540.

Sinha, R., Herat, S., Valani, B., and Krunalkumar, C. (2009). "Earthworms: The 'unheralded soldiers of mankind' and 'farmer's friend' working day and night under the soil: Reviving the dreams of Sir Charles Darwin for promoting sustainable agriculture," Am. J. of Ag. and Envi. Sci.5, 01-55.

Suthar, S. (2006). "Potential utilization of guar gum industrial waste in vermicompost 
production," Bio. Tec. 97(18), 2474-2477.DOI: 10.1016/j.biortech.2005.10.018

Suthar, S., and Gairola, S. (2014). "Nutrient recovery from urban forest leaf litter waste solids using Eisenia fetida," Ecol. Engine.71, 660-666.DOI: 0.1016/j.ecoleng.2014.08.010

Tacon, A. J., Stafford, E. A., and Edwards, C. A. (1983). "A preliminary investigation of the nutritive value of three terrestrial lumbricid worms for rainbow trout," Aqua. 35,187-199. DOI: 10.1016/0044-8486(83)90090-X

Tandon, S., (1993). "Methods of analysis of soils, plants, waters and fertilizer," Fertilizer Development and Consultation Organization, New Delhi. India.

Tripathi, P., and Bhardwaj, B. (2004). "Earthworms in waste and environmental management," Biores. Tech. 92, 275-283. DOI: 10.1016/j.biortech.2003.09.005.

Tohidinejad, E., Madani, H., and Jenabi, M. (2011). "Organic fertilizers and vermicompost," Shahid Bahonar University of Kerman Publications, Kerman, Iran.

Vodounnou, D. S., Juste, V., Kpogue, D. N., Apollinaire, M. G., and Didier, F. E. (2016). "Culture of earthworm (Eisenia fetida), production, nutritive value and utilization of its meal in diet for Parachanna obscura fingerlings reared in captivity," Intern. J. of Fish. Aqua. Stu. 4(5), 1-5.

Zakaria, Z., Rahayu, A., MohdSalleh, N., and SitiNursheela, A. (2013). "Total nitrogen content from earthworm Eisenia fetida using the Kjeldahl method," IIUM Engi. J. 14(1), 43-51.

Zhenjun, S., Xianchun, L., Lihui, S., and Chunyang, S. (2010). "Earthworm as a potential protein resource," Ecol. of Food Nutr. 36(2-4), 221-236. DOI: 10.1080/03670244.1997.9991517

Article submitted: June 17, 2019; Peer review completed: November 3, 2019; Revised version received: November 13, 2019; Accepted: November 25, 2019; Published: December 3, 2019.

DOI: $10.15376 /$ biores.15.1.574-587

Erratum: March 30, 2020, Minor editorial changes were made with spacing between words. 